possible to do without this, but it is useful in many ways in a hospital, and its use safeguards an operation in many points where error may creep in. The one chosen was the one devised by Lautenschläger of Berlin, and is furnished with two copper cylinders, one inside the other. In the centre one are placed the dressings, contained in two round boxes (cartridge cases they are sometimes termed), with apertures in them which permit of hot steam permeating their contents. This steam may be generated in the instrument itself, as is usually the case, or it may be obtainable from some other source and may be forced in. In either case there is an arrangement for condersing the vapours escaping from the apparatus in a cooling vessel which stands beside it. I find from the matron of our hospital that during the period it has been in use this steriliser has worked very well.

I considered it advisable to provide special apparatus for furnishing a liberal supply of sterilised hot and cold water for washing wounds and for other purposes during operations, so that I could be sure that only water previously sterilised by boiling would come into contact with the field of operation. This is done by the use of two copper sterilisers heated by gas and holding several gallons of water (see Fig. 3). Two are necessary as cold water is sometimes needed.

It is not possible to exclude septic cases from an operating theatre, but when they are within its walls every care should be taken that they do as little harm as possible. Hence it is very necessary to have included in the furnishings a box with well-fitting lid for all solled dressings to be at once placed in so that no discharges may fall on to the floor. The box selected is seen in Fig. 4 and is of a size to go undermeath the operating table. It is on rollers so as to allow of its being easily moved about and, if necessary, removed from the theatre.

The only other article I would allude to is the bottle and dressing stand which is seen in Fig. 3. It was made by Gardner and Son of Edinburgh and is very useful. On its shelves can be placed various articles, and its top, which is protected by a rail, can be made available for the glass reservoir jars for lotions, thus doing away with the need of a shelf for them to stand on.

Such, briefly, is a sketch of the operating theatre at the Glasgow Cancer Hospital, and some months' experience has shown that it possesses all the necessary requirements. It has a warm, pure atmosphere, which is free from dust; it is pervaded by a good steady light; it is furnished with a plentiful supply of pure hot and cold water; and it is so constructed and equipped that it is quite in keeping with that one principle which, according to Schimmelbush, should anderlie the planning and arranging of every operating room from an aseptic point of view-viz., the provision of plenty of space and of every convenience for cleansing and disinrecting. All this has been obtained at a cost of under $\mathcal{E} 550$, which $I$ regard as a reasonable sum seeing that it includes the price of the floor, plastering and painting of walls, electric lighting, plumber's work, heating apparatus, and surgical furniture.

Glasgow.

\section{THE PECULIAR AGGLUTINATIVE ACTION OF BLOOD SERA UPON LIVE SPERMATOZOA.}

BY ROBERT L. PITFIELD,

ASSISTANT BACTERIOLOGIST, STATE BOARD OF HEATTH, PENNSYLYANIA.

THE lysogenic action of the various normal and immunised sera upon bacteria and living animal cells, as blood corpuscles, is a familiar phenomenon. The action can be studied in various ways, chiefly by Pfeiffer's well-known method of injecting bacteria and serum already immumised into the peritoneal cavity of a guinea-pig; or else by studying the effects, on the other hand, of foreign serum upon the cells of an animal by a postmortem examination with sections, \&c. As motile and highly specialised cells spermatozoa seem ideal for the purpose. I have used spermatozoa obtained from the seminal vesicles of various animals, studying the action of foreign sera upon them. These cells are acutely sensitive to the action of desiccation, heat, cold, acid, or alkali in excess, also to sugary syrups, glycerine metallic salts, protoplasmic poisons, and in general substances which abstract water from the protoplasm.

If the seminal tubes of a guinea-pig (killed by chloroform) bs opened and the contents examined microscopically there will be seen a dense mass of vibrating spermatozoa. If the fluid be diluted with 0.6 per cent. salt solution at $37^{\circ} \mathrm{C}$. these cells exhibit active free motion. If into this mixture a drop of the blood of a guinea-pig be admixed a curious phenomenon is to be noticed. The spermatozoa head for the leucocytes and cling to them, meanwhile lashing their tails violently. About the middle piece of the spermatozoa the red cells seem to cling as the place of least motion. Some of the cells head directly for the red corpuscles and adhere to them with the head. In a few minutes all of the organisms become clumped, but they may exhibit lashing motions for at least an hour if kept at $37^{\circ} \mathrm{C}$.

If a drop of the serum of a sheep be added to a drop of the suspension of spermatozoa in salt solution the cells become perfectly quiet in 20 minutes without any agglutination. If a drop of human serum be added to the same guinea-pig spermatozoa suspension active motion will cease and agglutinated clumps will form; at the end of five minutes action will have ceased. If the serum of a cat be mixed with the spermatozoa the action is the same as with the human serum only it is slower, 18 minutes. If the spermatozoa of dogs be mixed with the sera of sheep there will be an immediate paralysis of the cells and in two minutes they will be clumped and perfectly quiet.

Controls of the spermatozoa of dogs and sheep in salt solution exhibited active lashing movements at the end of six hours. A moderate amount of lysogenesis was noted in some instances, but it was not marked. The interesting fact seems to be that live motile animal cells act toward foreign sera as typhoid bacilli act toward typhoid serum, or any motile organism toward immunised serum. The spermatozoa of a guinea-pig immunised against diphtheria toxin were as susceptible to the action of dilute toxin as were the unimmunised spermatozoa in one experiment.

Philadelphia, U.S.A.

\section{Clinital aldes:}

\section{MEDICAL, SURGICAL, OBSTETRICAL, AND THERAPEUTICAL.}

\section{A CASE OF FXTRA-UTERINE FIBROID; ABDOMINAL SECTION ; RECOVERY.}

By C. Stanser Bowker, L.R.C.P. Edin., \&c.

I WAS sent for to see a married woman on Feb. 17th, 1898. When I got to the house I found the patient suffering intense abdominal pain, not specially localised. On examination I found a tumour of about the size of an ordinary orange situated in the mid-line in the hypogastric region; it was very hard and was freely moveable. I may here mention that the patient was enceinte, six months or thereabouts. I tried to alleviate the pain by various internal medicaments but to no purpose, the pain still persisting in spite of treatment. I therefore decided to open the abdomen on the following day (the 18th). The patient's version of the matter was that she had never discovered anything wrong until she had been pregnant about a month, when she found a lump in the left groin which gradually rose higher and higher until it reached the above-named position, when she sent for me in consequence of the intolerable pain.

The abdomen was opened on Feb. 18th. An in cision of from about two and a half to three inches in length was made immediately below the umbilicus in the median line and down to the peritoneum. A director was inserted and the peritoneum was slit up. The tumour was grasped, a ligature was applied, and the offending mass was removed, this being connected with the fundus of the uterus. The abdominal cavity was washed out and thoroughly cleansed from all blood and the wound was stitched up, the operation lasting barely ten minutes. The patient went on well without any interruption until the 20 th when 
labour pains set in. I immediately dilated the os and applied a small pair of forceps and delivered to prevent the patient using any undue force. From this time on there was a rapid recovery, the abdominal wound healing by first intention, the patient being allowed to leave her bed on the tenth day after the operation. The temperature never rose above $100^{\circ} \mathrm{F}$.

The only feature in the case which $I$ think may be interesting to readers of THE LANCET is the intense pain complained of. Whence did this pain originate? The tumour was an extra-uterine fibroid connected with the fundus uteri, but not, in my opinion, pressing on any nervous centre likely to cause so much pain as the patient evidently experienced.

Ilford.

\section{ARSENIC AS AN EXTERNAL IRRITANT}

Br A. MILson RoBerts, M.R.C.P. IREL., \&O.

ON May 18th a man, a gardener, called upon me with an erythematous redness and considerable puffiness of both legs and feet nearly as high as the knee. He also complained of sickness and diarrhoea and his tongue was covered with a slimy yellow fur. Under simple treatment he rapidly re. covered. The skin of the legs and feet desquamated. Just a month later he came to me again in rather a worse condition. There was a greater amount of erythema and the stomach and bowels were in a most irritable condition. Having in mind the violet powder poisoning cases with which I was connected in 1878,1 and being unable to account for the recurrence of the symptoms, except on the assumption of irritant poisoning, I elicited after some crossexamination that he bad been using a weed-killer and for two or three days on each occasion before the symptoms arose his boots and trousers had been thoroughly saturated with it. A rough analysis showed this weed-killer to contain a large quantity of arsenic.

Little Hadham.

\section{A CASE OF RETENTION OF URINE CAUSED BY RETAINED MENSTRUAL FLUID.}

By OLIver Smithson, M.R.C.S. ENG., L.R.C.P. Lond.

SoME weeks ago I was called to see a girl, aged 16 years, who could not pass urine and who was in great pain. On examining the patient I found the abdomen greatly swollen and could feel the bladder almost as high as the umbilicus. A draught of tincture of hyoscyamus and bicarbonate of potassium was administered and the girl put into a hot bath. This proving ineffectual, I passed a catheter and drew off a large quantity of urine, the pain being at once relieved. Whilst passing the catheter I felt a tense, fluctuating swelling projecting between the labia. The symptoms returned shortly afterwards and necessitated the use of the catbeter at regular intervals. Finding no cause for the retention I made another and more careful examination and then found that the swelling to which I have referred was an imperforate hymen bulging forward between the labia. With strict antiseptic precautions I incised the hymen, which was very tbick and leathery, and let out a quantity of menstrual fluid of very dark colour and extremely viscid in character. After this there was no further trouble, and the patient is now in excellent bealth. The retention was evidently caused by the great pressure of the menstrual fluid. The patient has several sisters older than herself who all started menstruating when about 13 years old, so that in all probability the menstrual fluid had been collecting for some considerable time.

Grays.

1 THE LANCET, Sept. 21st, 1878, p. 420.

Sanitary Matters at Truro.-At the meeting of the Truro City Council held on August 21st several of the members drew attention to the disregard of sanitation in the city, especially in the lower parts of it. It was stated that crude sewage was discharged into the river, and the town clerk mentioned that he bad received complaints as to the stench from the river. A member said that in a short time steps would be taken to compel the corporation to remedy the present state of affairs.

\section{A a dithror}

or

\section{HOS I T A L P ACTICE,} BRITISH AND FOREIGN. Fulla autem est alia pro certo noscendi via, nisi quamplnrimas et
morborum et dissectionum historias, tum aliorum tum proprias morborum et dissectionum historias, tum aliorum tum proprias corb lib ivere, et inter

\section{WESTERN OPHTHALMIC HOSPITAL.}

A CASE OF EPITHELIOMA OF THE CONJUNCTIVA; ENUCLEATION.

(Under the care of Mr. ARTHUR W. Wheatly.)

THE comparative rarity of seen and reported cases of malignant new growths affecting primarily the visible front of the eyeball appears to fully justify the narration of the following case. It is somewhat strange that after a duration of more than three years no involvement of the lymphatic glands in front of the ear should have been present; but the malignancy of epithelioma of the conjunctiva varies. greatly in different cases.

A hale old man, about 70 years of age, was admitted into the Western Ophthalmic Hospital under the care of $\mathrm{Mr}$ A. W. Wheatly on May 26th, 1899, for the treatment of a bleeding tumour of the left eye. According to the patient's. statement it must have been three years previously that it was first noticed that there was "something wrong with the eye," but he took little notice of it and only latterly had it proved a source of trouble to him. The main com plaint on admission was that the growth was evidently increasing somewhat rapidly in size, that it was sometimes the seat of pain, and that occasionally it bled, but the pain had always been bearable and the hrmorrhage had never been large.

On admission a warty growth was seen invading the outer fourth of the corneo-sclerotic region of the left eye. It was somewhat triangular in shape, the base being limited behind by the insertion of the left external rectus, above by the lower tendinous fibres of the superior rectus, and below by the external fibres of the inferior rectus, whilst the apex extended partly over the cornea and the pupil, and (in consequence of internal deviation of the eye) occluded the latter for practical purposes of vision. The growth was in all parts firmly adherent, its surface was papillomatous and friable, and it bled easily. It was densest in the region of the sclerotic adjacent to the cornea, measuring one-sixth of an inch in thickness in this situation. From here on June 2nd Mr. Wheatly removed a portion of the growth for microscopical examination, and having submitted it to a well-known authority received in due course the report which confirmed his worst suspicions as to its malignancy. It proved to be a squamous-celled epithelioma.

The case was watched for a time, but notwithstanding the fact that no glandular infiltration could be detected the growth was manifestly increasing and delay seemed to be dangerous. Enucleation was therefore advised and the patient's consent having been obtained $\mathrm{Mr}$. Wheatly performed the operation on June 16th, removing also such tissue as appeared to be in dangerous proximity.

Remarks by Mr. WhEaTLY.-I am much indebted to Mr. c. Devereux Marshall (pathologist to the Royal London Ophthalmic Hospital, Moorfields) who saw the patient prior to enucleation and who has since made a careful macroscopic and microscopic examination. He confirms the prior report and states that the growth is "a squamous-celled epithelioma which starts in the epithelium at the corneoscleral junction and can be traced and shown to be continuous with that covering the cornea. The growth is much infiltrated with small round cells and this is a secondary inflammatory change."

\section{ROYAL INFIRMARY, LIVERPOOL.}

A CASE OF PUERPERAL SEPTIC.EMIA IN WHICH ANTISTREPTOCOCCIC SERUM WAS USED WITH SUCCESS.

(Under the care of Dr. T. B. GRIMSDALE.)

$U_{P}$ to the present time a large number of cases have been. published in which anti-streptococcic serum has been 